\title{
Repositioning Common Property Right: An attempt to Govern Environment and Sustainable Natural Resources in Indonesia
}

\author{
Nanik Trih astuti \\ \{naniktrihastuti@gmail.com\} \\ Faculty of Law, Diponegoro University, 50275, Indonesia
}

\begin{abstract}
Common Property is a traditional notion that develops a sense of communal pride towards land belonging to all members of a community and prevents the land from degradation. A government dominated development and repressive law that have been implemented in Indonesia have marginalized a social system in terms of local wisdom and led to the degradation of ecological capital. The separation of customary rights and norms from legal systems and the policy of domination, ownership, and allocation of natural resources by overlooking common property have resulted in the loss of resource rights. By using a doctrinal legal approach and progressive reasoning, it could be concluded that the loss of resource rights towards resources due to the absence of property rights might cause individuals or groups to have no legal right, which allows them to prohibit other parties to consume the resources. To ensure one's property rights and tenure rights, the relationship between the government and the society needs to be evaluated towards the democratic model paradigm in order to acknowledge common property in the legislation and uphold it as an alternative strategy to reduce externality.
\end{abstract}

Keyword:Reposition, collective property rights, environmental and sustainable natural resources, Indonesia

\section{Introduction}

Universal property rights that traditionally exist and maintain the balance of the utilization of natural resources in Indonesia have been marginalized due to the increasing number of the human population and the use of forests as plantations and mining. Traditional and local institutions have also suffered from degradation due to the pressure from the market and the state institutions that impose the monoculture system or uniformity on pluralistic community institutions. Thus, there is a shift in the values and the norms in everyday life, including in the management of natural resources. The use of the notion of sole proprietorship towards land, which applies open and unlimited access; and has become the basis of the economic and political policy formulation regarding to natural resources, has led to the poor management of natural resources that is not in line ${ }^{1} \mathrm{With}$ environmental sustainability. The system in the market economy, which becomes the economic and political reference of the country, has been proven to impose the change of ownership of natural resources from a common resource into state property and private property.

${ }^{1}$ I would like to thank Prof. Dr. Heru Susanto, the chief of Research Institutes and Public Service of Diponegoro University, for providing the funding for this research. 
Furthermore, the tenure policy is not used as the foundation for the state policies to regulate the ownership of natural resources. Thus, these resources become a single and commercial commodity. This phenomenon may demonstrate that there could be a denial of the nature of natural resources, which is supposed to be inseparable from the social and cultural systems in society[1]. The role of the State, individuals, and collectivism in regulating common property resources has been a subject debated in the literature [2].

In the local people's view, resource tenure is a cultural product that is bound up with the rule of law and customs existing in their group. Property rights can be obtained due to the long-term relationship between the society, the land, and the natural resources upon which they depend (Linch \& Harwell, 2002). Indigenous people, as the owner of universal property rights, who have the inner and emotional bonding with natural resources along with their spiritual values, tend to be separated from the property rights due to the government's public policy.

There are several cases that can be evidence to suggest that the government's public policy has resulted in the displacement of indigenous people from their land for example, the displacement of the indigenous community in Semende residing in Banding Agung, Bengkulu due to the enactment of Law number 18 Year 2013 regarding the Prevention and Eradication of Forest Destruction [3]. Another case is that Suku Anak Dalam (a tribe), who lived in Taman Nasional Bukit Tigapuluh and Taman Nasional Bukit Duabelas in Sarolangun-Batanghari Jambi, was brutally displaced from their land in Kampung Tanah Menang, Pinang Tinggi, Padang Salak, and Bukit Terawang by some oil palm and rubber companies from 1987 to 2013. This displacement led to death as the area of the indigenous people's land decreased.[3]. The government's partiality towards companies may prove that the government may have overlooked the fundamental values of law, that is, equality, freedom, and solidarity that require recognition towards the equality, the rejection against abuse of power, and the belief that we are united as one country.

The main aim of the management of the living environment is to preserve the safety and the sustainability of life, but this may lead to conflicts if it clashes with political interest and economic power. The modern science utilized in the management of natural resources may ease the system and make it efficient. However, on the other hand, it may not be able to understand and interpret the complexity of ecological systems and contribute to the realization of sustainable environmental management. Therefore, this may result in ecological crises and conflicts related to living areas. In this sense, living areas do not merely refer to the land or the house to live in, but it also means all the life-supporting systems, including the system of knowledge and its institutions.

\section{Methodology}

This study used a doctrinal legal approach that conceptualizes law as a principle of justice within the moral system according to the doctrine of natural law and draws a conclusion based on the deductive syllogism[4]. The analysis utilized the progressive reasoning model to understand the legal process as a correction towards a conventional concept. Thus, it can be implemented at present [5]. The secondary data, legal materials, were the primary data in this research. 


\section{Findings}

\subsection{The Stance of Common Property Rights in Environmental and Sustainable Natural Resource Management}

Property rights are mostly a secure claim towards resources and services that are produced from those resources. Thus, these rights should be supported, as they may ensure one's ownership [6]. Bromley states that the regime can be a tool to control the use of natural resources and affect the relationship and the reliance between a particular group and another [7] [8]. Therefore, property rights of natural resources (about State Property, Private Property and Common /Communal Property which have open access and limited access) seem to be the significant issue for the success of the efficiency of the market and the allocation of resources.

As a traditional notion that develops a sense of communal pride towards land belonging to all members of a community and prevents the land from degradation, common property may show that there is a close relationship between the rights holders and their environment and natural resources (Fauzi, 2006) (however, in fact, their relationship with the nature is sometimes not harmonious). Their reliance on the environment and natural resources may trigger them to maintain the integrity of their ecosystem in order to preserve the sustainability of the accessibility of their needs based on the collective responsibility in terms of moral [9]. This responsibility can prevent them from damaging the nature.

Resource tenure owned by indigenous people can be seen from indigenous Dayak people, Kalimantan who differentiate the land into customary land and trust land [7]. Customary land is the land that belongs to individuals from a particular community and is recognized as one's property as long as the land tenure is recognized (only limited to the territory of the village). Meanwhile, trust land is the primary forest around the area, which is not used as a farm. Since this land is under guardianship, people who want to turn the forest into a farm should ask for permission from the guardian and give an offering to the spirit in the forest. Any violation of rights and obligations established may be imposed by the economic sanction, such as a fine, and required to hold a ceremony to clean up the environment and balance the nature according to their notion of resource tenure.

Resource tenure is a cultural product that is obtained due to the long-term relationship, physically and emotionally, between the society, the land, and the natural resources on which they rely on. It then produces traditional wisdom in the form of traditional institutions. These institutions are dominated by norms and ethics that emerge from cultures and beliefs as a regulation [8]. Moreover, resource tenure should encompass resource rights that are communal property reflecting bundle of rights such as, the rights to use, control, receive economic benefits, and the complex and overlapping symbolic rights may be still understood and obeyed by local groups of people.

The existence of the communities identified as indigenous people who tend to rely on natural resources may be essential to be understood as one of the groups that have a direct interest of the access to the resources, and that is vulnerable to the climate change.

The displacement and the lack of recognition of the existence of indigenous people and their cultures may diminish their local wisdom and change their behavior and norms regarding the management of natural resources. Thus, community institutions may not be active. If one or a group of people does not possess the property right, there might be no legal right, which can be used to prohibit other parties to consume the resources. Allowing property rights can be an effective way to reduce externality if the parties involved are known. 


\subsection{Common Property according to the Perspective of Justice}

As stated in Article 1 paragraph (2) The 1945 Constitution of the Republic of Indonesia, The State of Indonesia shall be a State based on the rule of law, in which the authority of the State should be conducted based on justice. Hence, two aspects need to be considered. First, the relationship between the government and the citizens is not based on power, but on objective norms binding the government. Second, the law is not only as a formal but also as an objective norm that can be maintained towards the idea of law[9]. The law should be fair in the sense that it is consistent with the society's expectation and the ultimate goal, that is justice. Therefore, the customary rights and norms may no longer be separated from the system and the policies regarding the control, ownership, and allocation of natural resources in Indonesia. This may be a required thing to do, so that as the communal rights holders, they may obtain their tenure security. Thus, the ecological crisis that is based on the viewpoint and the behaviour of modern society may be overcome using the involvement of the local wisdom, defined as one's behaviour when interacting with nature and its surroundings originated from his/her value of customs and local cultures [10] and the ethics of indigenous people. Indeed, this local knowledge is considered as essential for human dignity in the community [11].

Aiming for a welfare state through the democratic government should be able to place the state as an institution that is responsible for the society's welfare by applying public policies related to economy and social, and promoting the efficiency of economy, reducing poverty, reinforcing social equality, developing social integration or avoiding social exclusivity, ensuring social stability and self-independence [12]. The implication of implementing the notion of the welfare state may enlarge the government's duty, in which the State should be active and responsible for running the human resource development so that it can achieve the optimal welfare. Thus, the government applies "discretionary power" to develop its society [13]. In terms of the welfare state, sovereignty tends to be superior to disinterestedness, so the State is no longer bound up to the notion of pluralism, but is more associated with an authoritarian state. The characteristic of the authoritarian state is that the government interprets the State as merely the government rather than the government and society. The implication of this superficial interpretation could be that the relationship between the government and the society might be super-subordinate, meaning that the government may regard themselves as superior to the society. According to Nurjaya [14], this type of relationship may reflect the developmental model being used, that is, a government dominated development. To support this implementation, repressive law is designed, which on the one hand recognizes the collective property right; but on the other hand, this right is limited and explicitly overlooked in the legislation. As a result, the universal property right, which is supposed to contribute to the environmental management and the utilization of natural resources, may not be upheld.

The establishment of conservation areas in order to preserve the forestry sector may demonstrate that the government's policy regarding the management of natural resources may be based on the assumption that humans are separated from nature. Indigenous people in these areas are relocated and displaced from their land. They are also prohibited from utilizing resources available in the forest. This policy may clash with customary law because this law does not differentiate the regulation of landform of the forest. Thus, the type of rights to land also determines the status of the forest.

Before the reformation era, the forest management in Indonesia was regulated using Law number 5 the Year 1967, which is considered as exploitative since it prioritizes economic interest. Hence, in the reformation era, this law was amended by Law number 41 the Year 1999 on Forestry, which uses Law number 5 the Year 1960 as the foundation to regulate 
forestry sector. This regulation is deemed to take the society's interest into account and more democratic, and in line with the philosophy of the management of natural resources as stated in Article 33 paragraph (3) The 1945 Constitution of the Republic of Indonesia.

The idealism reflected in Law number 41 the Year 1999 may not be able to reduce the forest destruction, and even the destruction seems to get worse. This is caused by this law, which tends to be central-oriented, gives more power to the central government in the regulation and management of the forestry sector.

According to Article 5 paragraph (1) Law number 41 the Year 1999 on Forestry, the forest is categorized based on its status and functions, that is, state forest and title forest. State forest refers to any forest on land not charged with land title, while title forest means any forest situated on land charged with land title. Based on Article 1 (f) Law number 41 the Year 1999, indigenous forest means state's forest situated in the indigenous law community area.

Article 5 paragraph 1 Law number 41 the Year 1999 also states that forest control for land management shall be given to indigenous communities. As the indigenous forest is state forest, the obligations imposed on indigenous communities are the same as other users.

According to the normative aspect, this regulation is consistent with Article $18 \mathrm{~B}$ paragraph (2). The 1945 Constitution of the Republic of Indonesia stated that the State recognizes and respects traditional communities along with their traditional customary right. It is permissible as long as these remain in existence and are by the societal development and the principles of the Unitary State of the Republic of Indonesia, and the law shall regulate it. It is also in line with Article 28 I paragraph (3) The 1945 Constitution of the Republic of Indonesia stating that the development of times and civilizations shall respect the cultural identities and rights of traditional communities. Therefore, these provisions may imply that the owner of the land and natural resources in the State. Thus, it has a right to allocate resources to any parties that can offer economic advantage.

This may contradict Article 1 paragraph (1) Law number 5 the Year 1960 on Basic Regulations on Agrarian Principles stating that the entire territory of Indonesia is a unified motherland of the whole of the Indonesian people who are united as the Indonesian Nation. Thus, it is the Indonesian Nation that owns the whole of Indonesian areas. Meanwhile, Article 2 paragraph (1) and (2) states that the earth, water, and airspace, including the natural resources contained therein, are in the highest instance controlled by the State is an Authoritative Organization of the whole People; to regulate and implement the appropriation, the utilization, the reservation and the cultivation of that earth, water and air space; to determine and regulate the legal relations between people concerning the earth, water and air space. Furthermore, paragraph (3) states that authority is exercised in order to achieve the maximum prosperity of the people.

Law number 41 the Year 1999 Article 68 paragraph (3) and (4) states that the community in and around the forest shall be entitled to compensation against loss of access to surrounding forest as an employment opportunity to fulfill their daily need due to forest area designation according to the prevailing legislation. Each person shall be entitled to compensation against loss of their title to land they own due to forest area designation according to the prevailing legislation.

The establishment of forest areas sometimes does not involve indigenous/ local communities that have been living in the area for a long time. The compensation offered is not always appropriate as it is done without any in-depth examination regarding customary law in the area. In this sense, the government perhaps has not learned from their mistakes in determining the area for transmigration, leading to conflicts between the local people and the transmigrants due to the lack of understanding of customary law of both parties. 
Hence, it can be concluded that what the State does is eliminating property rights, and this is considered as going beyond what the State is supposed to do. As the authority, the State only owns economic rights from agrarian resources. The State can only make a legal agreement regarding economic rights with other parties as a basis to manage agrarian resources. Thus, the goal that is to fulfill the most significant benefit of the people as stated in Article 33 paragraph (3) The 1945 Constitution of the Republic of Indonesia and Article 1 paragraph (3) Law number 5 the Year 1960 on Basic Regulations on Agrarian Principles may not be accomplished.

\subsection{Reposition of Common Property Rights}

Similar to other property rights, universal property rights have been regulated in the welfare economic system in Indonesia, as stated in Article 33 paragraph (4) of The 1945 Constitution of the Republic of Indonesia. The acknowledgment of this property right requires bright, firm, and fair legislation in order to be upheld because common property resources may be at risk of overuse and degradation[15] [16]. According to the theory of the enforcement of the law, the law is considered as being enacted if it is regulated. Thomas Aquinas says that law is forcefully enacted. In order to make the law have binding legal force, it should be applied to the given subject. In order to make the society obey the regulations, positive law should be fair and able to bound up with the people's awareness including (1) goal aspect, meaning that any positive law should be regulated for the benefit of the people; (2) authority aspect, meaning that positive law should be designed according to the constraints of constitution; (3) form aspect, meaning that positive law should give obligations to the legal subject accordingly.

The implementation of public policies is considered as unfair as it is based on the wrong understanding and assumptions regarding natural resources. It leads to misery for certain parties as shown in the separation between land and forest, so basic understanding and the assumption of natural resources should be re-examined. The re-conceptualization that agrarian does not merely mean land, but also covers a variety of aspects including economy, social, politics, and cultures[16] may be required. Tenure policies are also not related to the change of the relationship between people and the land or the resources but are associated with the change of the social and power relations among social groups. Based on this definition, the owner, the user, the regulator of resources, including who controls the access to other parties if the resources are damaged and who benefits from the resources, can be determined. Realizing the justice may be achieved through the wisdom of the authority to create regulations that can embody traditional values existing among the society because it is these values that develop the State without overlooking the value of state absolutism that has the power in the politics and law [17]. Therefore, the law may no longer be a static entity, but both customary and state law can be complementary. The state based on the rule of law should honor and ensure the protection of human rights for all its people, including the right to cultures and values embodied in the traditional cultures.

The pattern of the relationship between the government and the citizens should be evaluated. The model of classic-central oriented and super-subordination should be shifted to the standard mode suggesting that the state's power is not absolute; rather, fundamental individual rights should be the primary concern. As the State is based on the rule of law, the government should honor and ensure the protection of human rights for all the citizens, including the right to cultures and values among indigenous people. 
The Constitution should not be understood as a regulation with its positive and usual norms, but the Constitution is a result of expression from a doctrine. Thus, the principles of freedom and liberty that are no longer "slave" but "citizens" can be examined [4].

The notion of constitution that becomes the foundation of the State and is "supreme" in democratic life can be restored into its two essential doctrines, that is, freedom doctrine as an "interrogable" and "inalienable" fundamental human right so it should be whole and unblemished, and "Rule of Law" doctrine stating that law has the highest position compared to any norms. Thus, regarding the context of the protection of human rights and the management of natural resources, the attempt to realize the justice may be achieved through the wisdom of the authority to create regulations that can embody traditional values existing among the society. These values develop the State without overlooking the value of state absolutism that has the power in politics and law [17]. Therefore, the law may no longer be a static entity, but both customary and state law can be complementary.

To avoid the disintegration in a multicultural state, the characteristic of law that should be promoted is the law that is responsive, meaning that the law responds to and accommodate values, principles, norms, institutions, and tradition that grow within the society.

\section{Conclusion}

The reposition of universal property rights is an alternative way to reduce externality in the management of natural resources. The reposition of universal property rights requires a change in the power relationship between the State and its citizens into a more democratic model, meaning that the authority of state officials are derived from the rights of their citizens. Thus, it is limited. In this case, there is an equal position between the State and its citizens in the development of the country.

The establishment of universal property rights through the formulation of legislation should be done so these rights can be upheld. To formulate this public policy, in addition to the re-conceptualization of the definition and the assumption used as the rationale for making the policies related to agrarian and tenure policies, the government is required to allow the society to take parts as they have gone through the impact of the planning stage. That way, a comprehensive understanding of the society's perspectives needs, and expectations can be achieved, which results in inappropriate decision-making. The government should run the multi-aspect development of the country so that welfare and justice can be harmonious without overlooking the fact that this State is plural.

\section{Acknowledgments}

First of all, I would like to thank Dr. Purwanto, SH., M.Hum, as the chief of Research Institutes and Public Service of Panca Bhakti University Pontianak, West Kalimantan, for his assistance in collecting the data for this research. I would also like to thank Salfius Eko, a lecturer in Faculty of Law in Tanjungpura University, Pontianak and the chief of DayakTobak Institute in Sanggau, West Kalimantan for providing useful information required in this research.

I am grateful to Lingkar Borneo community for giving information related to the research site. Last but not least, I am also immensely grateful to Dr. Hadiyanto, MSc, the supervisor of the Research Team, for the advice and assistance in writing this research. 


\section{References}

[1] S. Keraf, Krisis dan Bencana Lingkungan Hidup Global, Crises and Globally Environmental Disasters. Yogyakarta: Kanisius, 2010.

[2] L. A. ; A. K. German, "Hybrid institution: Applications of common property theory beyond discrete property regimes," Int J Commons, vol. 4, pp. 571-596, 2010.

[3] Forum Keadilan, Forum Keadilan. 2015.

[4] S. Wignjosoebroto, Hukum Paradigma. Metode dan Dinamika Masalahnya), Law. Jakarta: ELSAM HUMA, 2002.

[5] S. Rahardjo, Hukum Dalam Jagat Ketertiban. Jakarta: UKI Press, 2006.

[6] R. Attfield, The Ethics in the Global Environment. Edinburgh: Edinburgh University Press, 2010.

[7] Kartodiharjo; Jhamtani, Politik Lingkungan dan Kekuasaan di Indonesia. Jakarta: Environmental Politics and Power, 2006.

[8] S. Keraf, Etika lingkungan. Jakarta: Kompas, 2002.

[9] S. F, Etika Politik. Jakarta: Gramedia Pustaka Utama, 1994.

[10] V. R. Vitasurya, "Local wisdom for sustainable development of rural tourism: Case on Kalibiru and Lopati village, Province of Daerah Istimewa, Yogyakarta," Soc Behav Sci., vol. 16, no. 2, pp. 97-108, 2016.

[11] C. Geertz, The Interpretation of Cultures. New York: Basic Books Inc. Publishers, 1973.

[12] Y. Latif, Negara Paripurna: Historisitas, Rasionalitas, dan Aktualitas Pancasila, "Paripurna" State: History, Rationale for, and Actuality of Pancasila. Jakarta: Gramedia Pustaka Utama, 2011.

[13] M. Mahfud MD, Demokrasi dan Konstitusi di Indonesia: Studi tentang Interaksi Politik dan Kehidupan Ketatanegaraan, Democracy and Constitution in Indonesia: A Study of Political Interaction and Constitution. Bandung: Rineka Cipta, 2003.

[14] F. Wiryani, Reformasi Hak Ulayat: Pengaturan Hak-Hak Masyarakat Adat dalam Pengelolaan Sumber Daya Alam, Communal Land Rights: The Regulation of Indigenous People's Rights in the Management of Natural Resources. Malang: Setara Press, 2009.

[15] R. Heltberg, "Property rights and natural resource management in developing countries," J Econ Surv, vol. 16, pp. 189-214, 2002.

[16] G. Wiradi, Tanah dan Air dalam Konteks Reforma Agraria, Land and Water in the Context of Agrarian Reformation. Jakarta: Mahkamah Konstitusi, 2004.

[17] M. Erwin, Filsafat Hukum. Jakarta: Raja Grafindo Persada, 2015. 